When Does Public Information Undermine the Efficiency of Reverse Auctions for the Purchase of Ecosystem Services?

Kent D. Messer ${ }^{1}$, Joshua M. Duke ${ }^{1}$, Lori Lynch $^{2}$ and Tongzhe $\mathbf{L i}^{1}$

${ }^{1}$ Department Applied Economics and Statistics, University of Delaware, ${ }^{2}$ Department of Agricultural and Resource Economics, University of Maryland and the USDA Economic Research Service

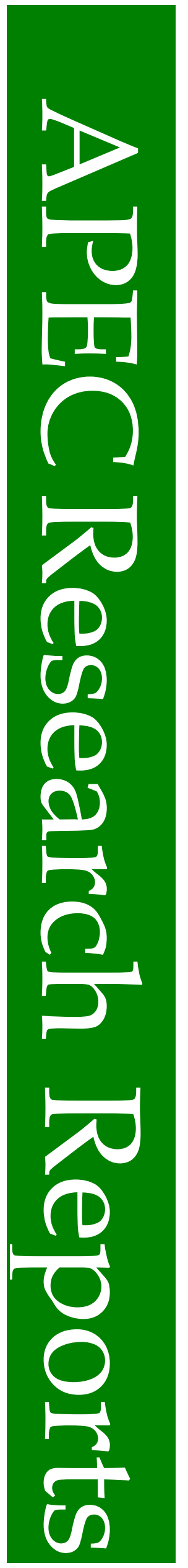




\section{ABSTRACT \\ When Does Public Information Undermine the Efficiency of Reverse Auctions for the Purchase of Ecosystem Services?}

Keywords: reverse auctions, purchase of ecosystem services, conservation auctions, auction efficiency, land preservation

Government conservation agencies that conduct reverse auctions traditionally provide a significant amount of public information about past auction results. This information includes not only the amount of money spent by the government but also can include the number of offers received, number of offers accepted, highest accepted bid, lowest accepted bid, and the average accepted bid. This research uses induced-value experiments to evaluate the effect of past auction information on seller rent seeking. Results from 140 participants suggest that sellers use some public information to learn how to secure higher rents. However, when sellers are given information only about the buyers' budget, they secure lower rents. Results also suggest that relative budget size affects rents and that budget variability in the presence of market information diminishes the effect. Thus, in the presence of public information and equivalent total outlays, variable budgets are more likely than stationary budgets to achieve conservation auction fiscal efficiency. Finally, this research finds that auctions with greater heterogeneity in seller opportunity costs are less fiscally efficient than when the distribution is more homogeneous.

\section{For additional information on this research course, contact:}

Kent D. Messer

E-mail: messer@udel.edu

Joshua M. Duke

E-mail: duke@udel.edu

Lori Lynch

E-mail: lori.lynch@ers.usda.gov

Tongzhe Li

E-mail: tongzhe@udel.edu

\section{Suggested Citation for APEC Research Reports}

Messer, K.D., J.M. Duke, L. Lynch, T. Li. 2016. "When Does Public Information Undermine the Efficiency of Reverse Auctions for the Purchases of Ecosystem Services?" Applied Economics \& Statistics Research Report, University of Delaware, RR16-04. 


\section{When Does Public Information Undermine the Efficiency of Reverse Auctions for the Purchase of Ecosystem Services?}

\section{Introduction}

Increasingly, governments use reverse auctions for purchases of environmental services (PES) associated with public goods. One goal of government programs in using reverse auctions is to achieve fiscal efficiency, i.e., maximizing PES relative to the budget. In the ideal case, this means that PES projects are enrolled at their unobservable but heterogeneous opportunity costs in a wellfunctioning auction. Information asymmetries, information provision, and strategic incentives can potentially affect auction efficiency. This paper evaluates auction efficiency in an experimental setting, using several realistic institutional variables with information treatments.

Competition-based policies such as reverse auctions are part of a broader trend for PES (Horowitz, Lynch, and Stocking, 2009). The U.S. Department of Agriculture's (USDA's) Conservation Reserve Program (CRP) is one long-running example in which landowners submit offers indicating the amount of compensation they would require to enroll in the program and the environmental practices they would be willing to undertake for a period of ten to fifteen years. At the end of December 2015, CRP had enrolled 365,617 farms comprising 24.3 million acres and was paying \$1.6 billion in rent annually (USDA, 2015). Two examples of reverse auctions outside the United States are Australia’s Auction for Landscape Recovery (Gole et al., 2005) and Bush Tender pilot trials (Stoneham et al., 2003). Stoneham et al. (2003) found that the Bush Tender program would have cost the government seven times more if fixed prices had been used instead of a reverse auction. Others include the United Kingdom's Challenge Funds and initial auctions for greenhouse gas reductions and Germany’s Grassland pilot. Competition-based processes are 
likely to be important components of future U.S. policies addressing major environmental issues such as nonpoint water pollution and total maximum daily load regulations.

Prior studies (reviewed in the next section) have demonstrated that reverse-auction efficiency depends on the institutional and information regimes used; but the interactions of those elements remain mostly unexplored. One challenge is a difficulty in determining exactly how much information sellers have in a given auction environment. Economic experiments provide control over information provision, including all parameters and induced values, and help explain the influence of that information on auction efficiency. This paper uses experiments to answer four research questions about how changes in the public information available to potential sellers affect the ability of sellers to capture rent premiums in a discriminatory reverse auction:

1. Do rent premiums change when information on past market behavior is made public?

2. Do rent premiums change when the buyer's budget changes in different periods?

3. Do rent premiums change when opportunity costs are more heterogeneous?

4. Do rent premiums change when market information is provided and the buyer's budget varies in different years?

Table 1 provides a summary of the hypotheses, significance thresholds, and results of the tests of the hypotheses related to these questions. Thus, this paper assesses the budgetary costeffectiveness of a PES auction — which is equivalent to fiscal efficiency because PES benefits are assumed to be homogeneous - in terms of institutional designs that vary by the transparency of the auction mechanism and the consistency of the buyer's budget. The experiment incorporates two information treatments, two distributions of sellers' ownership returns, and two types of budgetsstable and variable. The research analyzes the effect of interactions between the degree of public information provided and heterogeneity and budget uncertainty on discriminatory auction 
efficiency. In addition, the experiments examine the effects of participant learning on the auction results. The results show that public information leads to significant rent-seeking behavior, particularly when the buyer's budget is high. However, some factors mitigate the sellers' rents, including limiting the amount of public information provided, using a budget that varies in different years, and using reverse auctions when the opportunity costs are relatively homogeneous.

\section{Literature Review}

Reverse auctions have been used widely for PES, both in the United States and throughout the world (Duke, Dundas, and Messer, 2013). An extensive economic literature has compared the efficiency of auctions to other approaches and considerable attention has been given to discriminatory auctions between conservation agencies and landowners (Hanley et al., 2012). Recent work focuses on the performance of auctions for PES in budget-constrained settings with information-revealing, learning, and/or dynamic rounds (Hong and Shum, 2002; Parkhurst and Shogren, 2003; Rolfe et al., 2011; Schilizzi and Latacz-Lohmann, 2012, 2013; Fooks, Messer, and Duke, 2015). In addition, attempts have been made to offer second-best corrections of the information asymmetry (Arnold, Duke, and Messer, 2013) and to model benefits as spatially interdependent (Fooks et al., 2016).

\section{Rent-seeking}

Rent-seeking behavior results in a rent premium (bid shading), which refers to the gap between a landowner's ownership-return (opportunity cost) function and the bid function (Schilizzi and Latacz-Lohmann, 2013), and has been documented in many studies. For instance, LataczLohmann and Schilizzi (2005) found that the optimal strategy for landowners was to inflate their 
offers. Sellers who had the lowest opportunity costs tended to inflate offers the most; those whose opportunity costs were closer to the cut-off ratio inflated less and made offers that were closer to their true reservation values. Kirwan, Lubowski, and Roberts (2005) found that CRP had spent between 10 and 40 percent of its budget on rents. Horowitz, Lynch, and Stocking (2009) found auction competition drives down bids but not landowners' reservation values; on average, bids were 5 to 15 percent above their underlying reservation values. Connor, Ward, and Bryan (2008) looked at the cost effectiveness of land conservation auctions relative to uniform price payments and negotiated agreements and concluded that cost-effectiveness is an empirical question that depends on the institution's structure, the budget, and the information environment.

\section{Learning in Reverse Auctions}

Some studies have suggested that experience with an auction mechanism both decreases uncertainty and improves efficiency. For example, Latacz-Lohmann and van Hamsvoort (1997) found that bidder uncertainty determined the relative cost of a set of purchases in an auction. They also theorized that a high level of uncertainty could lead to an inefficient outcome and strategic behavior by bidders. Cummings, Holt, and Laury (2004) also found that strategic rent-seeking behavior can develop when uncertainty is high. Klemperer (2002) reported that allowing sellers to learn about others' valuations through multiple rounds could make the sellers more comfortable with their own assessments and less cautious in making offers.

Several studies noted, however, that landowners' bids tended to be for the amount of the conservation agencies' maximum bid cap after the first few rounds of the auction (Shoemaker, 1989; Khanna and Ando, 2009). Similarly, Schilizzi and Latacz-Lohmann (2007) found that both target-constrained and budget-constrained auctions performed better than a fixed-price program in 
a one-shot setting but that, with repetition, seller learning quickly diminished the advantage of the auction. Therefore, incorporating learning in an experiment captures the ability of reverse auction participants to process information on past auction outcomes and the potential for extra rent in the future.

\section{Information about Sellers}

The optimal level of information provision has been most intensively studied aspect of PES auction design. In general, studies found that hidden information about landowners' opportunity costs decreases efficiency despite the fact that PES auctions were initially viewed as a way to force landowners to reveal their true opportunity costs (McAfee and McMillan 1987).

\section{Information about Buyer's Goals}

The role of incomplete information about the conservation agency's benefit has not been determined. Some studies have suggested that provision of information about the conservation agency generally increases auction efficiency, while others have concluded that revealing such information decreases efficiency because it incentivizes bidders to inflate their offers. In strategic settings, provision of a greater amount of information was found to benefit the buyers (Duffy and Feltovich, 2002; Devetag, 2003). Ferraro (2008) suggested that information disclosure enhances the perceived transparency and fairness of an auction, which can have positive long-term effects on participation and compliance. Krishna (2010), on the other hand, suggested that anything that deters competition, such as transparency, simplicity, and neutrality, will reduce the potential cost effectiveness of an auction. In the context of PES, Glebe (2013) analyzed a theoretical model and 
found that information disclosure improves efficiency by incentivizing entry by new landowners and competition between them.

Several studies nonetheless suggest that concealing information can be beneficial. Vincent (1995) finds that the auctioneer should not reveal all information in common-value auctions, which are typical of many conservation program auctions. Cason, Gangadharan, and Duke (2003) found that the regulator's (conservation buyer's) expenses could be reduced by withholding information about the scoring of environmental services. Cason and Gangadharan (2004) examined information effects in discriminatory and uniform pricing schemes, finding that sellers who knew relatively more about how the government assessed the buyer's received environmental benefits were more likely to inflate their offers and obtain greater rents. Discriminatory auctions also led to inflation of offers but remained more cost-effective than uniform-price auctions.

Vukina et al. (2008) used a reduced-form model to examine how plot-specific environmental scores that, ceteris paribus, increase the probability of winning affect bids. Rolfe, Windle, and McCosker, (2009) concluded that, while providing more information can theoretically make the auction more transparent and increase competitiveness, it also can, in reality, provide sellers with information needed to bid more strategically and capture rents. Banerjee, Shortle, and Kwasnica (2011) found that auctions were quite sensitive to information known by each seller. As additional information was revealed, cost-effectiveness decreased because the enrolled parcels became more expensive; landowners submitted higher bids and many were overcompensated. Experiments by Haruvy and Katok (2013) indicated that objective disclosure (revealing the goals of the auction) reduces auction performance, and Banerjee, Kwasnica, and Shortle (2015) found that rent-seeking intensified when greater information was available and as bidders became more familiar with the auction mechanism. 
Information about buyer's budget and reserve price

Information about the agency’s budget influences bidding behavior (Hellerstein and Higgins, 2010). Katkar and Reiley (2007) suggested that revealing the reserve price could deter participation, making the bids less competitive. Hailu and Schilizzi (2004) found in a simulation analysis that if bidders can provide information to influence an agency's behavior, they could then game the system by submitting higher bids. In contrast, Bajari and Hortacsu (2003) found that auction outcomes were not affected by announcement of the reserve price or by the lack of one. Cramton, Shoham, and Steinberg (2006) suggested that announcing the reserve price could resolve focal-point issues and that bidders who had little information often were concerned about the fairness of the auction. This may be especially true when markets for the good being auctioned are thin, as is often the case with environmental services. Therefore, landowners may need assistance or have to incur a cost to develop appropriate bids. Cason, Gangadharan, and Duke (2003) found a similar result; sellers inflated their offers when they knew that the agency placed a high value on their properties. In this case, revealing the objective function and the mechanism by which each parcel's benefits were assessed reduced the auction's efficiency.

In sum, prior economic studies of auctions have shown that participant learning, the agency budget, and information revealed about market behavior influence the efficiency of discriminatory auctions. Whether that influence is positive or negative or involves complex interactions remain open questions. This study contributes to the literature by experimentally examining the impact of those factors on landowners' rent-seeking behavior. Specifically, this research tests the treatment effects of (i) revealed information on the market's past behavior, (ii) varying the buyer's budget 
in different rounds, and (iii) different distributions of ownership returns on participants' bidding behavior over multiple rounds. Interaction effects are also modeled.

\section{Experimental Design}

In this study, 140 individuals participated in sessions at an experimental economics laboratory at a large public university in the northeastern United States. Participants were recruited via email to students in undergraduate courses in business and economics. Each participant earned approximately $\$ 25$.

Figure 1 depicts how participants in the experimental auction gain rents. Panel A shows that PES willingness-to-accept values (hereafter referred to with the term used in the experiment, “ownership returns”) increase with the supply of ecosystem service projects. In this experiment, the supply-and-demand relationship is drawn from a uniform distribution ranging from $\$ 1,500$ to $\$ 8,500$ per acre for each of the 100 -acre parcels. The budget of $\$ 8.7$ million intersects the supply curve at 21 parcels; thus, with perfect price discrimination, the conservation program would purchase the least expensive parcels available and would acquire 21 of 30 parcels available. If sellers inflate their offers, as shown in Panel B, the program could not buy as many parcels because they now cost more; the program exhausts its budget after purchasing only 16 parcels. Assuming that the ownership return fully captures the owner's willingness to accept PES - that the full current and future pecuniary and nonpecuniary values of the landowner from owning the land, the ownership return should represent the owner's indifference between retaining the land or selling it to the conservation program. Thus, any payment that exceeds the seller's ownership return represents a landowner rent and an efficiency loss for the government. 
Table 2 describes the experimental design in detail. In the first set of experiments, which consisted of 45 rounds, the budget was set at $\$ 8.7$ million and a uniform distribution of ownership return was used. In the second set of experiments (15 rounds), the budget amount varied and the distribution was uniform, and in the third set of experiments (15 rounds), the budget amount varied and a normal distribution of ownership values was used.

The participants were randomly assigned to separate computer stations, and each computer was equipped with a privacy screen. Participants were unuable to communicate, or collude directly, with each other, but they could theoretically signal each other through their bidding behavior during a session. After completing a consent form, the participants read written instructions (see the appendix) and then listened to an oral description of the experiments presented in PowerPoint to ensure consistency.

As shown in table 2, each participant was assigned the role of a landowner who was endowed with three 100-acre parcels. The conservation benefits of all parcels were identical and did not depend on their spatial location. Each parcel's ownership return represented the landowner's current and future pecuniary and nonpecuniary benefits from not selling the land to the conservation agency. Since such values are difficult, if not impossible, to observe directly in actual conservation markets, each participant's ownership returns were private information to the owner-participant.

Ownership returns for each parcel were induced values, drawn from either a uniform or a normal distribution. The uniform distribution ranged from $\$ 1,500$ to $\$ 8,500$ per acre in increments of \$500 (in experimental dollars) that was each assigned to two parcels. The uniform distribution was designed to mimic agricultural areas in the mid-Atlantic and northeastern regions of the United States, which tend to be heterogeneous in value relative to agricultural areas of the Midwest 
because development is typically the highest and best use. In addition, the mid-Atlantic and northeastern regions are the most active areas in the country in terms of preserving agricultural lands. The more homogeneous normal distribution covered the same range $(\$ 1,500$ to $\$ 8,500)$ but the parcels were concentrated near the mean of $\$ 5,000$. This distribution was designed to represent geographic regions like the Midwest in which agricultural land values are not as variable.

Participants could submit an offer to sell all, some, or none of the three parcels. Those who submitted offers had to pay a $\$ 2,000$ submission fee per parcel offered. If the program selected the parcel, the seller received the offer price minus the submission fee. If an offered parcel was not selected, the participant received the ownership return minus the submission fee. Participants who refrained from submitting an offer receive the ownership return. The submission fee likely affected the bidding behavior of owners of parcels that were valued at close to the cut-off ratio since the fee would deter participants from offering parcels that had a lower probability of being chosen. Therefore, the number of potential sellers was endogenous in the experiments.

Since each parcel produced an identical conservation benefit, the agency's objective function is simply to maximize the number of parcels enrolled given its budget, i.e., select parcels offered at the lowest prices until the budget exhausts. All sessions used a discriminatory auction (i.e., pay what you offer) in which participants whose parcels were chosen received a payment equal to the offer price. Each round represented the beginning and end of the world for all parcels. Therefore, each round was considered independent; none of the values for the parcels' environmental benefits, the sellers' ownership returns, and the buyer's budget carried over to subsequent rounds. ${ }^{1}$

\footnotetext{
${ }^{1}$ This statement does not assume that the knowledge of the market was independent for each round. To the contrary, as will be discussed later, participants learned about the market quickly and incorporated this information into their selling decisions.
} 
In the stationary-budget treatment, the buyer's budget was $\$ 8.7$ million in each round (see table 2). The 45 rounds conducted in sessions with the stationary budget were designed to evaluate changes in seller behavior when detailed market-behavior information was publicly available. In the variable-budget treatments, a new budget was established at the beginning of each round by having a volunteer draw a labeled bingo ball from a bag. The amount of the budget ranged from $\$ 3.7$ to $\$ 13.7$ million with an average of $\$ 8.7$ million (table 2). The goal was to determine whether an unpredictable budget affected seller behavior.

Two public-information treatments were used (table 2). The budget-only information treatment serves as the control group for this research as the participants were only aware of the buyer's budget in the next round and were shown the buyer's budgets in previous rounds. In the market-behavior information treatments, the participants received both the budget information and information about previous behavior of the market and the sellers in the previous rounds of the experiment:

- Identification numbers for sellers whose parcels were selected ${ }^{2}$

- Total number of offers received

- Total number of offers accepted

- Lowest accepted offer

- Average accepted offer

- Highest accepted offer

The market-behavior information treatment reflects the actual auctions conducted by Delaware Agricultural Lands Preservation Foundation (DALPF), which annually publishes that information after making its acquisitions (Messer and Allen, 2010). DALPF was founded in 1991 and, to date, has spent more than $\$ 140$ billion and preserved more than 110,000 acres (Farmland Information Center, American Farmland Trust Status of State PACE Programs 2015), which is the

\footnotetext{
${ }^{2}$ Participants were listed by number and sellers were not otherwise identifiable to other participants.
} 
largest number of acres of agricultural land preserved per capita by any state (Delmarva Farmer 2010).

In the experiments, the public information was given to all participants regardless of the outcomes of their individual decisions. Of course, participants could also learn about the market through their experience, such as whether and which of their parcels sold for a particular offer price in a round. The participants' computers displayed historic private and public information.

\section{Results}

Figure 3 shows the difference in rents obtained from the market-behavior and budget-only treatments. With a stationary budget and uniform distribution of ownership returns, sellers were largely able to secure higher rents over time; the average surplus for the sellers increased from $\$ 1,559$ in round 1 to $\$ 2,312$ in round 45 in the market-behavior treatment (an increase of $48.3 \%$ ) and from $\$ 1,384$ in round 1 to $\$ 2,117$ in round 45 in the budget-only treatment (an increase of 53.0\%). Figure 3 also illustrates how information impacted offer inflation under a stationary budget and how quickly sellers learned to exploit the auction format. Overall, the rents captured in the market-behavior treatment $(\$ 2,275)$ were $17 \%$ higher on average than the rents captured in the budget-only treatment $(\$ 1,943)$. Further inspection shows that most of this difference occurred in the initial rounds. The average rent captured in the first round was just $\$ 175$. In the second round, it jumped up $469 \%$ to $\$ 996$, suggesting that sellers learned to increase their offers and still succeeded in selling with the more robust set of public information provided.

The results suggest that the government was overcompensating landowners in part because it was providing them with the information needed to better strategize. Though not as quickly and never as dramatically, seller inflation also occurred in the budget-only treatment, leveling out near 
round 12. Furthermore, the average inflation amount exceeded $\$ 2,250$ only twice and occurred relatively late in the session.

Table 3 offers a formal test of the drivers of rent. Using a panel data set with a generalized linear regression with random effects and robust standard errors in which observations were clustered at the group level, we regressed the natural log of the average group-level rents obtained by successful sellers in a round on a binary variable related to the information treatment (the market-behavior treatment equaled 1), the number of the round, and a variable that captured the interaction of the treatment and round. Rent was defined as the price paid to the seller for a parcel minus the ownership return. A small average rent implies that the auction was relatively efficient. The round-number variable controls for seller experience going into the round in question. We expect that participants’ offers will be more accurate and/or more strategic as they gain experience. All else equal, greater experience should result in more certainty in how and when it is best to make an offer given the budget and potential number of other sellers. Additional experience could also allow other participants to discover ways to extract higher rent premiums.

Model 1 (stationary budget, uniform ownership returns) includes all 45 rounds. Based on the Wald statistic, the model explains a statistically significant amount of variation in rents. The results also show that public information about the behavior of successful sellers increased sellers' rents by $24.2 \%$, thus providing an initial answer to the question of whether market information affects the rent premiums. Additionally, sellers generally increased rents as they gained experience with the auction. With each round, their rents increased by $0.73 \%$ on average. However, the interaction term for market-behavior information and the round number was not statistically different from zero, which is consistent with the result shown in figure 3-the rents captured under the two information treatments converges over time. 
Model 2 limits the data analysis of model 1 to the first 15 rounds. ${ }^{3}$ In this model, the effect of public information about the market behavior and the round number were again significant and positive $(+37.2 \%$ and $+2.6 \%$ respectively). This result for the market-behavior information treatment again rejects the hypothesis that information on market behavior has no effect on rents (table 1). The interaction term is negative and significant $(-2.0 \%)$, indicating that the effect of public information on market behavior is strongest in the early rounds and then diminishes. Even without the additional market information, sellers secured higher rents as they learned about the market through repeated experience with the private ownership returns and accepted and rejected offers.

The independent variables included in the regression of model 3 (see table 3) allow us to address all four primary questions simultaneously. The market-behavior information indicator was included and was compared to the budget-only information treatment. A binary variable indicated whether the budget varied (variable $=1$ ), and the interaction of market-behavior information and a variable budget was designed to evaluate whether a variable budget in the presence of market information would diminish rents.

The variable Budget(ln) controlled for the impact of the variations in the budget. Larger budgets should lead to a greater number of parcels enrolled or to higher rent premiums for the same number of parcels. In reality, relatively large budgets also imply that there is less competition for a fixed number of sellers. If a higher budget induces more sellers to enter the auction, competition could increase, which would drive down rents. A binary variable was included to

\footnotetext{
${ }^{3}$ Models 2 and 3 were limited to 15 rounds because the effect of public information diminishes over time and few actual conservation auctions have been conducted more than 15 times. The smaller number of rounds allowed us to focus on the potential impacts of a variable budget and different distributions of ownership returns.
} 
capture whether the ownership returns were drawn from a uniform or a normal distribution (the variable took a value of 1 when the distribution was uniform).

The regression results support the experimental results-public information on the market's behavior had a positive and significant (+16.1\%) effect on seller rents. Information about the market's behavior allows sellers to secure additional rent premiums (question 1). The coefficient of Budget(ln) is also positive and significant, suggesting that larger budgets also lead to higher rents (question 2). For every 1\% increase in the budget, successful sellers inflated their offers by $0.48 \%$. Recall that the participants in these experiments knew the buyer's budget before submitting offers so they clearly were making upward adjustments to the offers when budgets appeared to be relatively large. In most cases of actual conservation auctions, potential sellers would know the amount of the budget, especially for government agencies, but there are times when that information is not known in advance. ${ }^{4}$

The coefficient of the binary variable identifying a uniform distribution is statistically significant and positive, providing an answer to our third question: settings involving relatively heterogeneous ownership returns allow successful sellers to capture greater rent premiums. This result confirms earlier findings such as Latacz-Lohmann and Schilizzi (2005) that sellers who have the lowest opportunity costs often inflate their offers the most. This idea is captured in figure 1 , which shows that low-cost landowners can, under a uniform distribution, significantly raise the amount of their offers and still likely succeed in selling their parcels. Thus, auctions involving parcels that vary considerably in value tend to less cost-effective than ones in areas characterized by fairly similar landowner returns. Program administrators have little control over returns to

\footnotetext{
${ }^{4}$ See Messer, Duke, and Lynch (2014), which showed that providing no budget information in advance could actually lead to higher rent premiums because, in the absence of any expectations, the seller may seek higher rents with the hope that the budget will be large.
} 
ownership so they may need to be especially careful about providing public information when variations in land quality and other factors result in a heterogeneous distribution of opportunity costs. $^{5}$

The regressions provide tentative support for the idea that a variable budget reduces the amount of rent captured by sellers who have access to information about the market (question 4). In that case, the rent premiums declined $12.3 \%$, which is marginally statistically different from zero $(p=0.098)$. A potential explanation for this result is that, with a variable budget, participants could not learn about the market as quickly so successful sellers could not raise their offers as much. Changes in the budget made it difficult to determine what the highest accepted offer would likely be.

As expected, the coefficient on the variable for the number of the round was positive and significant. Sellers learned more about how to secure additional rents with each subsequent round. In these experiments, the selling decision was modeled as a one-time choice. The robustness of the coefficient on the number of rounds suggests that landowners might benefit from waiting out the first few auction rounds. They could potentially generate higher rent premiums by observing the behavior of other landowners and the program's response in those early rounds. Or landowners could participate in the initial rounds but make outrageously high offers as a way to determine how the program evaluates a parcel's worth and/or benefits and then use that information when submitting genuine offers in later rounds. However, lack of landowner participation already

\footnotetext{
${ }^{5}$ Note that if the average opportunity costs a very homogeneous and the nonpecuniary benefits of landownership has little variability, then it the local government agency is likely to known this cost information and may be able to set a simple and cheaper fixed cost procedure.
} 
plagues some conservation auctions so it is not clear what would happen if all of the landowners follow a "wait and see” strategy. ${ }^{6}$

\section{Conclusion}

Government agencies use reverse auctions to purchase environmental services since markets for such services are negligible or nonexistent. Given the competition between potential sellers in an auction, landowners should have an incentive to reveal their reservation values. However, several studies have suggested that landowners tend to inflate their offers for a variety of reasons: uncertainty, reserve prices, experience, and information that allows them to behave strategically. In particular, conservation agencies may believe that providing information to the public and potential enrollees is important to ensure transparency and political fairness and that, by decreasing uncertainty, it can increase auction efficiency. In some cases, regulations may require public disclosure of previous market results.

Experimental approaches allow researchers to determine the true valuations and then elicit responses to a variety of treatments. We extend the literature on reverse auctions by determining whether the provision of public information regarding the market's behavior in the past resolves auction participants' uncertainty and allow them to make offers that are more truthful and/or more strategic. We also examine the degree to which the information affects sellers' tendency to inflate their offers based on the size of the budget and the role of learning during the auction when public information on the market's behavior is provided. Finally, we test whether heterogeneity in

\footnotetext{
${ }^{6}$ Recently, Maryland suspended their crab license buy-back auction because participation was low particularly with the low opportunity cost sellers. The lack of competition within the auction format resulted in the state proposing a take-it-or-leave-it program. Interestingly, some sellers agreed to the fixed price offer even though their bids were higher than the fixed price. Similarly, some sellers who had offered lower values did not take the fixed price offered (DePiper, et al., 2013).
} 
ownership returns affects whether offers are inflated and examine the effect of public market information on that interaction.

The results of the study suggest that conservation auctions are less efficient when agencies reveal detailed information about previous auctions under two of the treatments. Larger budgets and access to information about the market allow sellers to achieve higher rent premiums. We also find that landowners in a market characterized by heterogeneous ownership values secure higher rent premiums than owners in markets in which the ownership value are relatively homogeneous. This occurs primarily because there is a larger number of low-cost parcels under the uniform distribution and those sellers could inflate offers the most. Consequently, in regions such as the Midwest in which there is little difference in the agricultural returns between parcels, landowners will have little opportunity to inflate offers much beyond their reservation values. As a result, conservations programs in those regions should be able to achieve their objectives relatively costeffectively. 


\section{$\underline{\text { References }}$}

Arnold M, Duke J M, and Messer K D (2013) Adverse selection in reverse auctions for ecosystem services. Land Economics 89(3): 387-412

Bajari P, and Hortacsu A (2003) The winner's curse, reserve prices, and endogenous entry: Empirical insights from eBay auctions. RAND Journal of Economics 34(2): 329-355

Banerjee S, Shortle J S, and Kwasnica A M (2011) An iterative auction for spatially contiguous land management: An experimental analysis. Paper presented at the 2011 annual meeting of the Agricultural and Applied Economics Association, Pittsburgh, Pennsylvania 103220, 24-26 July 2011

Banerjee S, Kwasnica A M, and Shortle J S (2015) Information and auction performance: A laboratory study of conservation auctions for spatially contiguous land management. Environmental and Resource Economics 61(3): 409-431

Cason T N, and Gangadharan L (2004) Auction design for voluntary conservation programs. American Journal of Agricultural Economics 86(5): 1211-1217

Cason T, Gangadharan L, and Duke C (2003) A laboratory study of auctions for reducing nonpoint source pollution. Journal of Environmental Economics and Management 46: 446471

Connor J D, Ward J, and Bryan B A (2008) Exploring the cost effectiveness of land conservation auctions and payment policies. The Australian Journal of Agricultural and Resource Economics 52(3): 303-319

Cramton P, Shoham Y, and Steinberg R (2006) Combinatorial auctions. Cambridge, Massachusetts

Cummings R G, Holt C A, and Laury S K (2004) Using laboratory experiments for policymaking: An example from the Georgia irrigation reduction auction. Journal of Policy Analysis and Management 23(4): 341-363

Delmarva Farmer (2010) Markell proposes cuts to ag land preservation. January. Available at http://www.americanfarm.com/publications/the-delmarva-farmer/archives/473-markellproposes-cuts-to-ag-land-preservation (accessed January 2016).

DePiper G S, Higgins N, Lipton, D W, and Stocking, A (2013) Auction design, incentives, and buying back Maryland and Virginia crab licenses. Canadian Journal of Agricultural Economics 61(20): 353-370

Devetag G (2003) Coordination and information in critical mass games: an experimental study. Experimental Economics 6(1): 53-73

Duffy J, Feltovich N (2002) Do actions speak louder than words? An experimental comparison of observation and cheap talk. Games and Economic Behavior 39(1): 1-27

Duke, J.M., S.J. Dundas, and K.D. Messer (2013) Cost-Effective Conservation Planning: Lessons from Economics. Journal of Environmental Management 125: 126-133 
Farmland Information Center (2015) Status of State PACE Programs.

http://www.farmlandinfo.org/sites/default/files/State_Purchase_of_Agricultural_Conserv ation_Easement_Programs_2015_AFT_FIC_0.pdf. Accessed February 20, 2016.

Ferraro, P J (2008) Asymmetric information and contract design for payments for environmental services. Ecological Economics 65(4): 810-821

Fooks J, Higgins N, Messer K D, Duke J M, Hellerstein D, and Lynch L (2016) Conserving Spatially Explicit Benefits in Ecosystem Service Markets: Experimental Tests of Network Bonuses and Spatial Targeting. American Journal of Agricultural Economics 98(1): 1-21

Fooks J, Messer K D, and Duke J M (2015) Dynamic Entry, Reverse Auctions, and the Purchase of Environmental Services. Land Economics 91(1): 57-75

Glebe T W (2013) Conservation auctions: should information about environmental benefits be made public? American Journal of Agricultural Economics 95(3): 590-605

Gole C, Burton M, Williams K, Clayton H, Faith D P, White B, Huggett A, and Margules C (2005) Auction for landscape recovery: final report. World Wildlife Fund. Perth, Australia

Hailu A, and Schilizzi S (2004) Are auctions more efficient than fixed price schemes when bidders learn? Australian Journal of Management 29(2): 147-168

Hanley N, Banerjee S, Lennox G D, and Armsworth P R (2012). How should we incentivize private landowners to 'produce' more biodiversity? Oxford Review of Economic Policy 28(1): 93-113

Haruvy E, and Katok E (2013) Increasing revenue by decreasing information in procurement auctions. Production and Operations Management 22(1): 19-35

Hellerstein D, and Higgins N (2010) The effective use of limited information: do bid maximums reduce procurement costs in asymmetric auctions? Agricultural and Resource Economics Review 39(2): 288-304

Hong H, and Shum M (2002) Increasing competition and the winner's curse: Evidence from procurement. Review of Economic Studies 69: 871-898

Horowitz J K, Lynch L, and Stocking A (2009) Competition-based environmental policy: an analysis of farmland preservation in Maryland. Land Economics 85(4): 555-575

Katkar R, and Reiley D H (2007) Public versus secret reserve prices in eBay auctions: Results from a pokémon field experiment. The B.E. Journal of Economic Analysis \& Policy. DOI: $\underline{10.2202 / 1538-0637.1442}$

Khanna M, and Ando A W (2009) Science, Economics and the Design of Agriculture Programs in the US. Journal of Environmental Planning and Management 52: 575-592

Kirwan B, Lubowski R N, and Roberts M J (2005) How cost-effective are land retirement auctions? : Estimating the difference between payments and willingness to accept in the conservation reserve program. American Journal of Agricultural Economics 87(5):12391247 
Klemperer P (2002) What really matters in auction design. Journal of Economic Perspectives 16(1): 169-189

Krishna V (2010) Auction theory 2nd edition. Academic Press

Latacz-Lohmann U, and Schilizzi S (2005) Auctions for conservation contracts: A review of the theoretical and empirical literature. Report to the Scottish Executive Environment and Rural Affairs Department. Project No: UKL/001/05

Latacz-Lohmann U, and Van Hamsvoort C (1997) Auctioning conservation contracts: A theoretical analysis and an application. American Journal of Agricultural Economics 79(2): 407-418

McAfee R P, and McMillan J (1987) Auctions and bidding. Journal of economic literature 25(2): 699-738

Messer K D, and Allen W L (2010) Applying optimization and the analytic hierarchy process to enhance agricultural preservation strategies in the state of Delaware. Agricultural and Resource Economics Review 39(3): 442-456

Messer K D, Duke J M, and Lynch L. (2014) Applying experimental economics to land economics: Public information and auction efficiency in land preservation markets. In: Duke J M and Wu J (eds) The Oxford Handbook of Land Economics, Oxford Press

Parkhurst G M, and Shogren J F (2003). Evaluating incentive mechanisms for conserving habitat. Natural Resources Journal 43: 1093-1299

Rolfe J, Greiner R, Windle J, and Hailu A (2011). Testing for allocation efficiencies in water quality tenders across catchments, industries and pollutants: a north Queensland case study. Australian Journal of Agricultural and Resource Economics 55(4): 518-536

Rolfe J, Windle J, and McCosker J (2009) Testing and implementing the use of multiple offering rounds in conservation auctions: A case study application. Canadian Journal of Agricultural Economics 57: 287-303

Schilizzi S, and Latacz-Lohmann, U (2007) Assessing the performance of conservation auctions: An experimental study. Land Economics 83: 497-515

Schilizzi S, and Latacz-Lohmann, U (2012) Evaluating conservation auctions with unknown bidder costs: The Scottish fishing vessel decommissioning program. Land Economics 88(4): 658-673

Schilizzi S, and Latacz-Lohmann, U (2013) Conservation tenders: Linking theory and experiments for policy assessment. The Australian Journal of Agricultural and Resource Economics 57(1): 15-37

Shoemaker R (1989) Agricultural Land Values and Rents under the Conservation Reserve Program. Land Economics 65(2): 131-137

Stoneham G, Chaudri V, Ha A, and Strappazon L (2003) Auctions for conservation contracts: An empirical examination of Victoria's bush tender trial. Australian Journal of Agricultural and Resource Economics 47(4): 477-500

United Stated Department of Agriculture (2015) Conservation reserve program. Enrollment activity and news - February 2015. 
http://www.fsa.usda.gov/Internet/FSA_File/feb2015summary.pdf. Accessed February 20, 2016.

Vincent, D R (1995) Bidding off the wall: Why reserve prices may be kept secret. Journal of Economic Theory 65(2): 575-584

Vukina, T, Zheng, X, Marra M., and Levy, A (2008) Do farmers value the environment?

Evidence from a conservation reserve program auction. International Journal of Industrial Organization 26(6): 1323-1332 
Table 1. Research Questions and Hypotheses.

\begin{tabular}{|l|l|l|l|}
\hline Research Question & Hypothesis & Test & $\begin{array}{l}\text { Result and } \\
\text { interpretation }\end{array}$ \\
\hline $\begin{array}{l}\text { 1. Do rent premiums change } \\
\text { when information on past } \\
\text { market behavior is made } \\
\text { public? }\end{array}$ & Market_Behavior $=0$ & $p<0.01$ & $\begin{array}{l}\text { Reject. Providing past } \\
\text { market behavior } \\
\text { information increases } \\
\text { rent premiums }\end{array}$ \\
\hline $\begin{array}{l}\text { 2. Do rent premiums change } \\
\text { when the buyer's budget } \\
\text { changes in different years? }\end{array}$ & Budget $=0$ & $p<0.01$ & $\begin{array}{l}\text { Reject. Rent premiums } \\
\text { increase as budget levels } \\
\text { increase. }\end{array}$ \\
\hline $\begin{array}{l}\text { 3. Do rent premiums change } \\
\text { when ownership returns are } \\
\text { more heterogeneous? }\end{array}$ & Uniform=0 & $p<0.01$ & $\begin{array}{l}\text { Reject. Rent premiums } \\
\text { increase when the } \\
\text { ownership returns are } \\
\text { more heterogeneous. }\end{array}$ \\
\hline $\begin{array}{l}\text { 4. Do rent premiums change } \\
\text { when market information is } \\
\text { provided and the buyer's } \\
\text { budget varies in different years? }\end{array}$ & Market_Behavior*Varying $=0$ & $p<0.10$ & $\begin{array}{l}\text { Marginally Reject. } \\
\text { When market } \\
\text { information is provided } \\
\text { to the public, rent } \\
\text { premiums appear to } \\
\text { decrease when budgets } \\
\text { vary. }\end{array}$ \\
\hline
\end{tabular}




\section{Table 2. Experimental Design}

\section{Common Design Elements}

Participants per group:

Initial endowment:

Length of contract:

Auction mechanism:

Submission fee:

Private information:

ii)
10

3 parcels, 100 acres, homogeneous conservation benefits

1 round

Discriminative auction

$\$ 2,000$ per parcel

i) Ownership returns for each parcel

Sales history for each parcel

Public information: Budget-Only-Information treatment

i) Budget in previous rounds

ii) Budget for next round

Market-Behavior-Information treatment

i) Budgets in previous rounds

ii) Budget for next round

iii) Which sellers sold parcels

iv) Total number of offers received

v) Total number of offers accepted

vi) Lowest Accepted Offer

vii) Highest Accepted Offer

viii) Average Accepted Offer

Design Elements

\begin{tabular}{|c|c|c|c|}
\hline 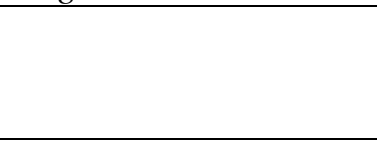 & $\begin{array}{c}\text { Design 1: } \\
\text { Stationary Budget }\end{array}$ & $\begin{array}{c}\text { Design 2: } \\
\text { Variable Budget, Uniform } \\
\text { Ownership Returns } \\
\end{array}$ & $\begin{array}{c}\text { Design 3: } \\
\text { Variable Budget, Normal } \\
\text { Ownership Returns } \\
\end{array}$ \\
\hline Number of Participants & 60 (6 sessions) & 40 (4 sessions) & 40 (4 sessions) \\
\hline Rounds per session & 45 & 15 & 15 \\
\hline Ownership returns: & Uniform Distribution & $\begin{array}{c}\text { Uniform } \\
\text { Distribution }\end{array}$ & $\begin{array}{c}\text { Normal } \\
\text { Distribution }\end{array}$ \\
\hline Buyer's budget & $\begin{array}{l}\text { Stationary } \\
\$ 8.7 \text { million }\end{array}$ & $\begin{array}{c}\text { Variable } \\
\$ 3.7 \text { to } \$ 13.7 \text { million } \\
\$ 8.7 \text { million on average }\end{array}$ & $\begin{array}{c}\text { Variable } \\
\text { \$3.7 to } \$ 13.7 \text { million } \\
\text { \$8.7 million on average }\end{array}$ \\
\hline
\end{tabular}


Table 3. Panel regression models of the seller rent premiums (in natural log form).

\begin{tabular}{|c|c|c|c|}
\hline Variable & Model 1 & Model 2 & Model 3 \\
\hline Constant & $\begin{array}{l}7.3933^{* * *} \\
(0.0388)\end{array}$ & $\begin{array}{l}7.2397^{* * *} \\
(0.0525)\end{array}$ & $\begin{array}{l}2.7170^{* * *} \\
(0.9918)\end{array}$ \\
\hline Market_Behavior & $\begin{array}{l}0.2419^{* * *} \\
(0.0659)\end{array}$ & $\begin{array}{l}0.3716^{* * *} \\
(0.1027)\end{array}$ & $\begin{array}{l}0.1614^{* * *} \\
(0.0236)\end{array}$ \\
\hline Round & $\begin{array}{l}0.0073^{* * *} \\
(0.0017)\end{array}$ & $\begin{array}{l}0.0255^{* * *} \\
(0.0035)\end{array}$ & $\begin{array}{l}0.0055^{* * *} \\
(0.0013)\end{array}$ \\
\hline Market_Behavior*Round & $\begin{array}{c}-0.0035 \\
(0.0022)\end{array}$ & $\begin{array}{c}-0.0197^{* * *} \\
(0.0063)\end{array}$ & \\
\hline Varying & & & $\begin{array}{c}-0.0268 \\
(0.0890)\end{array}$ \\
\hline Market_Behavior*Varying & & & $\begin{array}{c}-0.1231^{*} \\
0.0743\end{array}$ \\
\hline Budget(In) & & & $\begin{array}{l}0.4834^{* * *} \\
(0.1078)\end{array}$ \\
\hline Uniform & & & $\begin{array}{l}0.3333^{* * *} \\
(0.0648)\end{array}$ \\
\hline$\overline{\text { Obs }}$ & 270 & 90 & 390 \\
\hline Wald Chi ${ }^{2}$ & 467.54 & 63.79 & 381.77 \\
\hline Prob $>\mathrm{Chi}^{2}$ & 0.00 & 0.00 & 0.00 \\
\hline
\end{tabular}

Notes: Robust standard errors provide in parentheses.

*indicates statistical significance at the $10 \%$ level.

${ }^{* *}$ indicates statistical significance at the $5 \%$ level.

*** indicates statistical significance at the $1 \%$ level. 
Figure 1. Supply and demand in a conservation market with rent premiums, uniform distribution of ownership returns and a budget $=\$ 8.7$ million .

\section{Panel A}

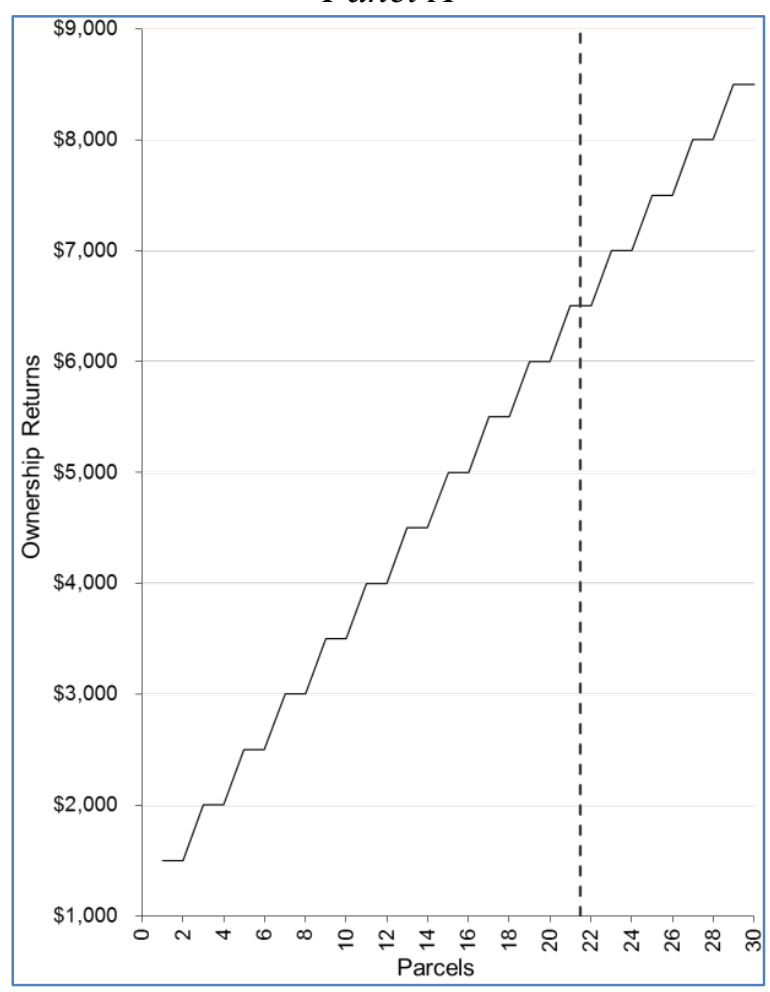

\section{Panel B}

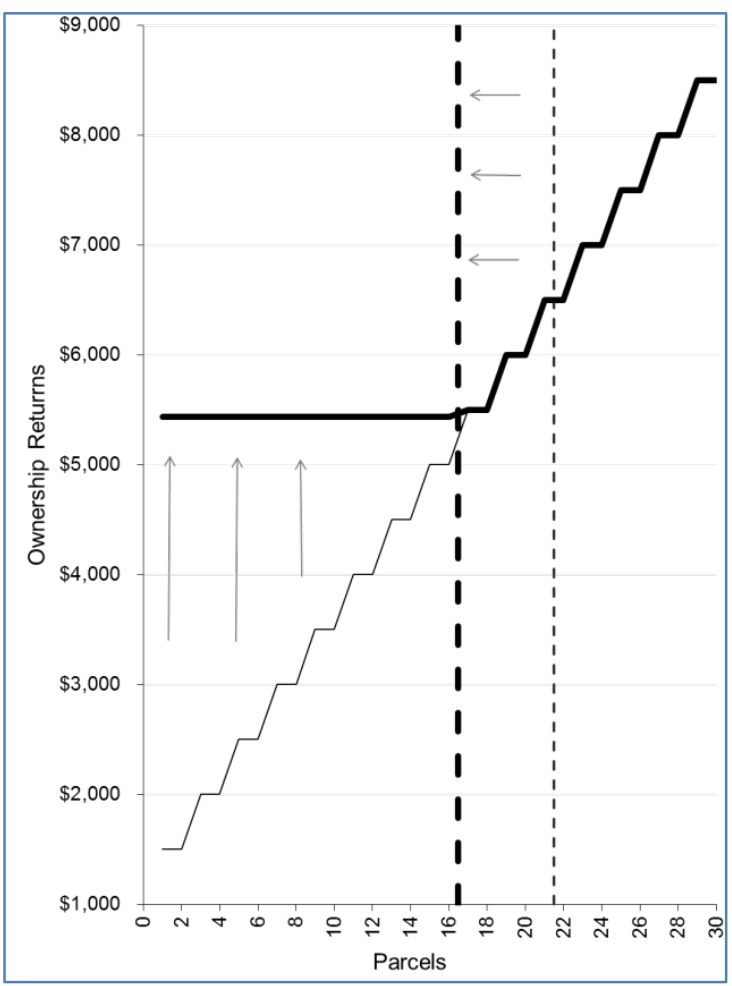


Figure 2. Distributions of ownership returns.

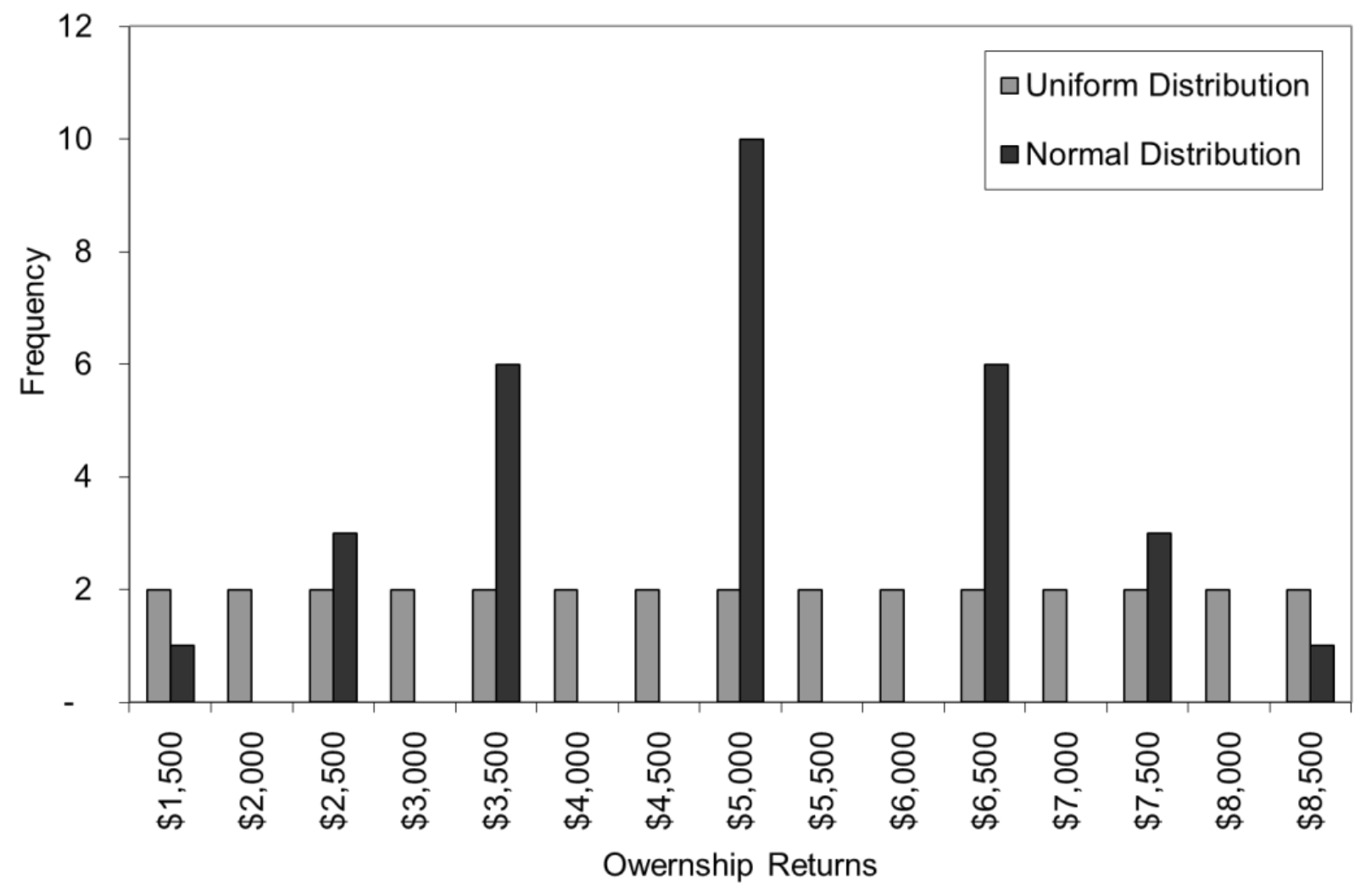


Figure 3. Rent Premiums Captured by Market Information

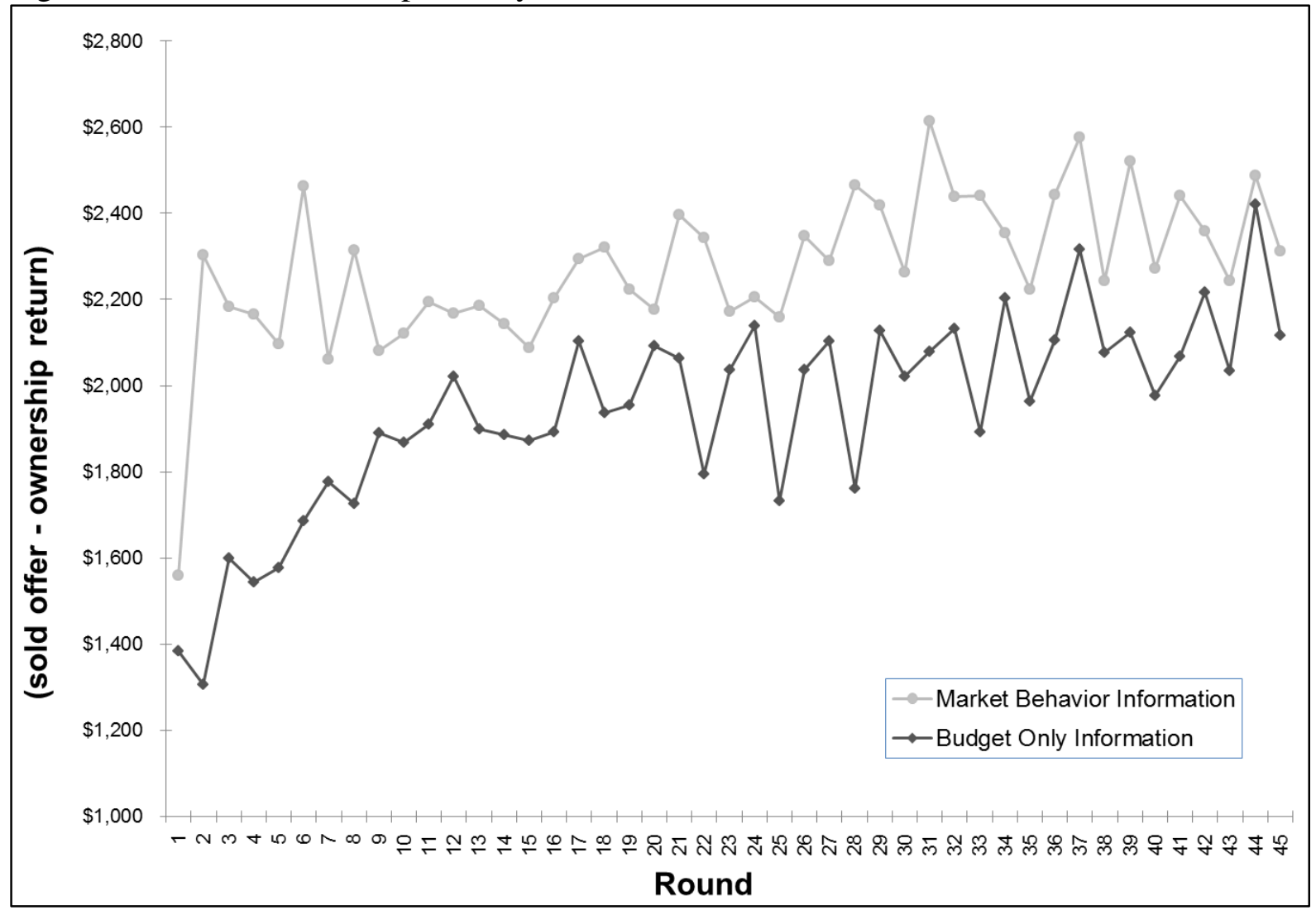




\section{$\underline{\text { Review Appendix - Experiment Instructions }}$}

\section{Experiment Instructions - Stationary Budget with Market Behavior Public Information}

Welcome to this experiment in the economics of decision making. In the course of the experiment, you will have opportunities to earn money. Any money earned is yours to keep. Therefore, please read these instructions carefully. Please do not communicate with other participants during the experiment.

In this experiment, you will participate in a series of market trading rounds. You and all of the other participants in the room will assume the role of landowners and you will be given the opportunity to sell up to three parcels of land. The administrator will be the buyer. In each round, you will need to decide whether you want to keep each of your parcels or try to sell some or all of them - and at what price you want to sell each parcel.

To the right is a hypothetical example, where two rounds have been completed and the third round is just about to begin. On your computer screen, you will note a variety of important information. Each parcel is assigned an Ownership Return per acre, which is the amount of money that will be added to your profit if that parcel is not sold in that round. The size of each of your three parcels is 100 acres each. In this hypothetical example, the ownership returns in the first round are \$300 per acre, \$500 per acre, and $\$ 600$ per acre, respectively. In general, your ownership returns may not be the same as those of other sellers and will change throughout the

\begin{tabular}{|c|c|c|c|c|c|c|c|}
\hline \multirow{7}{*}{ Parce1 1} & \multirow[b]{2}{*}{ Ownership Return per acre: } & \multicolumn{2}{|c|}{ Round 1} & \multicolumn{2}{|c|}{ Round 2} & \multicolumn{2}{|c|}{ Round 3} \\
\hline & & \multicolumn{2}{|r|}{300} & $\$$ & 100 & $\$$ & 1,000 \\
\hline & Offer Price per acre: & $\$$ & 500 & s & 150 & s & - \\
\hline & Submission Cost per acre: & $\$$ & 20 & $\$$ & 20 & $\$$ & - \\
\hline & Number of Acres: & & 100 & & 100 & & 100 \\
\hline & Sold: & & Yes & & Yes & & \\
\hline & Profit: & $\$$ & 48,000 & $\$$ & 13,000 & $\$$ & - \\
\hline \multirow{6}{*}{ Parce1 2} & Ownershio Return per acre. & $\$$ & 500 & $\mathbf{s}$ & 400 & $\mathbf{s}$ & 800 \\
\hline & \begin{tabular}{|l} 
Offer Price per acre: \\
\end{tabular} & & & $\mathrm{s}$ & 600 & S & - \\
\hline & Submission Cost per acre: & $\$$ & - & $\$$ & 20 & $\$$ & - \\
\hline & Number of Acres: & & 100 & & 100 & & 100 \\
\hline & Sold: & & & & No & & \\
\hline & Profit: & $\$$ & 50,000 & $\$$ & 38,000 & $\$$ & - \\
\hline \multirow{10}{*}{ Parce1 3} & Ownership Return per acre: & $\$$ & 600 & $\$$ & 400 & $\$$ & 100 \\
\hline & Offer Price per acre: & $\$$ & 800 & s & 500 & $\$$ & - \\
\hline & Submission Cost per acre: & $\$$ & 20 & $\$$ & 20 & $\$$ & - \\
\hline & Number of Acres: & & 100 & & 100 & & 100 \\
\hline & Sold: & & No & & No & & \\
\hline & Profit: & $\$$ & 58,000 & $\$$ & 38,000 & $\$$ & - \\
\hline & & \multicolumn{2}{|c|}{ Submit } & \multicolumn{2}{|c|}{ Submit } & \multicolumn{2}{|c|}{ Submit } \\
\hline & \multirow[t]{2}{*}{ Number of Offers: } & \multirow{2}{*}{\multicolumn{2}{|c|}{ Update }} & \multirow{2}{*}{\multicolumn{2}{|c|}{ Indate }} & \multirow{2}{*}{\multicolumn{2}{|c|}{ Update }} \\
\hline & & & & & & & \\
\hline & Tota1 Profit: & $\$$ & 156,000 & $\$$ & 89,000 & $\$$ & - \\
\hline
\end{tabular}
experiment. Keep in mind that the numbers used in these tables are for instructional purposes only and may not look at all like the numbers you will see during the experiment.

The buyer's budget will be $\$ 8.7$ million in each round. In each round, you must decide whether you want to sell any or all of your parcels and, if so, at what price you are willing to sell each of your parcels. To do this, first, you will indicate the number of offers that you will be typing 0,1 , 2 , or 3 in the blue box. You will pay a submission cost of \$20 per acre for each parcel for which you submit an offer. Next, you will submit your offer prices confidentially by entering them into the yellow boxes in your spreadsheet. Then, hit "Enter" on your keyboard, and click on the "Submit" button after you have entered offer prices for all of the parcels you are trying to sell. In this example for Round 1, two offers are being made: the offer prices are \$500 for parcel 1 and $\$ 800$ for parcel 3. 
After everyone has submitted their decisions, the administrator will rank all the offer prices received from lowest to highest and then determine which participants sold their parcels based on the budget for that round. The administrator will purchase as many parcels as possible starting from the lowest offer price and moving up until the available budget is exhausted. For example, imagine that current round budget is $\$ 300$ and eight offer prices were submitted - ranked from lowest to highest:

\begin{tabular}{lllllllll} 
Offer Prices: & $\$ 30$ & $\mathbf{\$ 4 0}$ & $\mathbf{\$ 5 0}$ & $\mathbf{\$ 6 0}$ & $\mathbf{\$ 7 0}$ & $\$ 80$ & $\$ 90$ & $\$ 100$ \\
\hline
\end{tabular}

Parcels are purchased in order (from left to right) until the buyer does not have enough money to purchase another parcel. In the example, the five lowest offer prices $(\$ 30+\$ 40+\$ 50+\$ 60+$ $\$ 70)$ are purchased for a total of $\$ 250$. None of the last three offers are purchased, since even the lowest non-accepted offer of $\$ 80$ would bring the total cost to $\$ 330(\$ 250+\$ 80)$ and therefore be higher than the buyer's budget.

\section{Determination of Profits}

After all offer prices have been received, the auctioneer will determine which parcels were purchased. You will then click on the "Update" button and you will learn whether you sold your parcels. There are three possible profit scenarios:

i) Successful sellers will receive a price equal to their offer, and thus, their profits will be their offer price for that parcel minus the submission cost.

ii) Participants that submit an offer for a parcel which is too high for the available budget will not receive their offer price, but instead their profits will be their ownership return for that parcel minus the submission cost.

iii) Profits for participants who do not submit an offer for a parcel will be their ownership return for that parcel.

In Round 1 of the example to the right, the subject earned a total profit of $\$ 156,000$ by successfully selling Parcel 1 for a profit of $\$ 48,000$, earning $\$ 50,000$ profit from Parcel 2 where no offer was submitted, and earning $\$ 58,000$ profit for Parcel 3 that was not successfully sold. Likewise, in round 2 of this example, the subject would earn a total profit of $\$ 89,000$ from selling Parcel 1 and receiving the ownership returns from Parcel 2 and Parcel 3 minus the submission costs for each. 
Your computer will calculate your profits for each parcel in each round, and will keep track of your cumulative earnings. An exchange rate of 3,000,000 to 1 will be used to converts your earnings from experimental dollars to US dollars. For example, if you earn 60,000,000 experimental dollars will have earned \$20 US to take home today.

\section{Market Information}

In addition to the information regarding your ownership returns and whether you sold your parcels, you will receive information regarding the market (as seen in the example):

Before each round, the administrator will announce:

- $\quad$ The buyer’s budget for that round (\$8.7 million).

After each round, the administrator will announce:

- The number of offers submitted to the market,

\begin{tabular}{|c|c|c|c|c|c|c|c|}
\hline \multirow{7}{*}{ Parcel 1} & \multirow[b]{2}{*}{ Ownership Return per acre: } & \multicolumn{2}{|c|}{ Round 1} & \multicolumn{2}{|c|}{ Round 2} & \multicolumn{2}{|c|}{ Round 3} \\
\hline & & $\$$ & 300 & $\$$ & 100 & $\$$ & 1,000 \\
\hline & Offer Price per acre: & s & 500 & s & 150 & \$ & - \\
\hline & Submission Cost per acre: & $\$$ & 20 & $\$$ & 20 & $\$$ & - \\
\hline & Number of Acres: & & 100 & & 100 & & 100 \\
\hline & Sold: & & Yes & & Yes & & \\
\hline & Profit: & $\$$ & 48,000 & $\$$ & 13,000 & $\$$ & - \\
\hline \multirow{6}{*}{ Parce1 2} & Ownership Return per acre: & $\$$ & 500 & $\$$ & 400 & $\$$ & 800 \\
\hline & Offer Price per acre: & & & s & 600 & $\$$ & - \\
\hline & Submission Cost per acre: & $\$$ & - & $\$$ & 20 & $\$$ & - \\
\hline & Number of Acres: & & 100 & & 100 & & 100 \\
\hline & Sold: & & & & No & & \\
\hline & Profit: & $\$$ & 50,000 & $\mathbf{s}$ & 38,000 & $\$$ & - \\
\hline \multirow{21}{*}{ Parce1 3} & Ownership Return per acre: & $\$$ & 600 & $\$$ & 400 & $\$$ & 100 \\
\hline & Offer Price per acre: & s & 800 & s & 500 & s & - \\
\hline & Submission Cost per acre: & $\$$ & 20 & $\$$ & 20 & $\$$ & - \\
\hline & Number of Acres: & & 100 & & 100 & & 100 \\
\hline & Sold: & & No & & No & & \\
\hline & Profit: & $\$$ & 58,000 & $\$$ & 38,000 & $\$$ & - \\
\hline & \multirow{3}{*}{ Number of Offers: } & \multicolumn{2}{|c|}{ Submit } & \multicolumn{2}{|c|}{ Submit } & \multicolumn{2}{|c|}{ Submit } \\
\hline & & \multicolumn{2}{|r|}{2} & \multicolumn{2}{|r|}{3} & \multirow{2}{*}{\multicolumn{2}{|c|}{ Update }} \\
\hline & & \multicolumn{2}{|c|}{ Update } & \multicolumn{2}{|c|}{ Update } & & \\
\hline & Total Profit: & $\$$ & 156,000 & $\$$ & 89,000 & \multicolumn{2}{|l|}{$\$$} \\
\hline & Next Round's Budget: & $\$$ & 2,200 & & & & \\
\hline & This Round's Budget: & $\$$ & 2,800 & & & & \\
\hline & Number of Offers Received: & & 12 & & & & \\
\hline & Lowest Accepted Offer: & $\$$ & 400 & & & & \\
\hline & Highest Accepted Offer: & $\$$ & 700 & & & & \\
\hline & Average Accepted Offer: & $\$$ & 500 & & & & \\
\hline & Sellers: & & 11 & & & & \\
\hline & & & 13 & & & & \\
\hline & & & 22 & & & & \\
\hline & & & 51 & & & & \\
\hline & & & 73 & & & & \\
\hline
\end{tabular}

- The price of the lowest accepted offer,

- The price of the highest accepted offer,

- The average price of the accepted offers, and

- The participants that successfully sold their parcels.

This information will be recorded on your spreadsheet when you click on the "Update" button after each round. 


\section{Experiment Instructions - Stationary Budget with Budget Only Public Information}

Welcome to this experiment in the economics of decision making. In the course of the experiment, you will have opportunities to earn money. Any money earned is yours to keep. Therefore, please read these instructions carefully. Please do not communicate with other participants during the experiment.

In this experiment, you will participate in a series of market trading rounds. You and all of the other participants in the room will assume the role of landowners and you will be given the opportunity to sell up to three parcels of land. The administrator will be the buyer. In each round, you will need to decide whether you want to keep each of your parcels or try to sell some or all of them - and at what price you want to sell each parcel.

To the right is a hypothetical example, where two rounds have been completed and the third round is just about to begin. On your computer screen, you will note a variety of important information. Each parcel is assigned an Ownership Return per acre, which is the amount of money that will be added to your profit if that parcel is not sold in that round. The size of each of your three parcels is 100 acres each. In this hypothetical example, the ownership returns in the first round are $\$ 300$ per acre, $\$ 500$ per acre, and $\$ 600$ per acre, respectively. In

\begin{tabular}{|c|c|c|c|c|c|c|c|}
\hline & & \multicolumn{2}{|c|}{ Round 1} & \multicolumn{2}{|c|}{ Round 2} & \multicolumn{2}{|c|}{ Round 3} \\
\hline \multirow{6}{*}{ Parce1 1} & Ownership Return per acre: & $\$$ & 300 & $\$$ & 100 & $\$$ & 1,000 \\
\hline & Offer Price per acre: & $\$$ & 500 & $\$$ & 150 & $\$$ & - \\
\hline & Submission Cost per acre: & $\$$ & 20 & $\$$ & 20 & $\$$ & - \\
\hline & Number of Acres: & & 100 & & 100 & & 100 \\
\hline & Sold: & & Yes & & Yes & & \\
\hline & Profit: & $\$$ & 48,000 & $\$$ & 13,000 & $\$$ & - \\
\hline \multirow{6}{*}{ Parce1 2} & Ownership Return per acre: & $\$$ & 500 & $\$$ & 400 & $\$$ & 800 \\
\hline & Offer Price per acre: & & & $\$$ & 600 & $\$$ & - \\
\hline & Submission Cost per acre: & $\$$ & - & $\$$ & 20 & $\$$ & - \\
\hline & Number of Acres: & & 100 & & 100 & & 100 \\
\hline & Sold: & & & & No & & \\
\hline & Profit: & $\$$ & 50,000 & $\$$ & 38,000 & $\$$ & - \\
\hline & & & & & & & \\
\hline \multirow{10}{*}{ Parce1 3} & Ownership Return per acre: & $\$$ & 600 & $\$$ & 400 & $\$$ & 100 \\
\hline & Offer Price per acre: & $\$$ & 800 & $\$$ & 500 & $\$$ & - \\
\hline & Submission Cost per acre: & $\$$ & 20 & $\$$ & 20 & $\$$ & - \\
\hline & Number of Acres: & & 100 & & 100 & & 100 \\
\hline & Sold: & & No & & No & & \\
\hline & Profit: & $\$$ & 58,000 & $\$$ & 38,000 & $\$$ & - \\
\hline & & \multicolumn{2}{|c|}{ Submit } & \multicolumn{2}{|c|}{ Submit } & \multicolumn{2}{|c|}{ Submit } \\
\hline & \multirow[t]{2}{*}{ Number of Offers: } & & 2 & \multirow{2}{*}{\multicolumn{2}{|c|}{ Update }} & \multirow{2}{*}{\multicolumn{2}{|c|}{ Update }} \\
\hline & & & Jpdate & & & & \\
\hline & Tota1 Profit: & $\$$ & 156,000 & $\$$ & 89,000 & $\$$ & - \\
\hline
\end{tabular}
general, your ownership returns may not be the same as those of other sellers and will change throughout the experiment. Keep in mind that the numbers used in these tables are for instructional purposes only and may not look at all like the numbers you will see during the experiment.

The buyer's budget will be $\$ 8.7$ million in each round. In each round, you must decide whether you want to sell any or all of your parcels and, if so, at what price you are willing to sell each of your parcels. To do this, first, you will indicate the number of offers that you will be typing $0,1,2$, or 3 in the blue box. You will pay a submission cost of $\$ 20$ per acre for each parcel for which you submit an offer. Next, you will submit your offer prices confidentially by entering them into the yellow boxes in your spreadsheet. Then, hit "Enter" on your keyboard, and click on the "Submit" button after you have entered offer prices for all of the parcels you are trying to sell. In this example for Round 1, two offers are being made: the offer prices are $\$ 500$ for parcel 1 and $\$ 800$ for parcel 3 . 
After everyone has submitted their decisions, the administrator will rank all the offer prices received from lowest to highest and then determine which participants sold their parcels based on the budget for that round. The administrator will purchase as many parcels as possible starting from the lowest offer price and moving up until the available budget is exhausted. For example, imagine that current round budget is $\$ 300$ and eight offer prices were submitted - ranked from lowest to highest:

\section{Offer Prices: \\ $\$ 30$ \\ $\$ 40$ \\ $\$ 50 \quad \$ 60$ \\ $\$ 70$ \\ $\$ 80$ \\ $\$ 90$ \\ $\$ 100$}

Parcels are purchased in order (from left to right) until the buyer does not have enough money to purchase another parcel. In the example, the five lowest offer prices $(\$ 30+\$ 40+$ $\$ 50+\$ 60+\$ 70)$ are purchased for a total of $\$ 250$. None of the last three offers are purchased, since even the lowest non-accepted offer of $\$ 80$ would bring the total cost to $\$ 330(\$ 250+\$ 80)$ and therefore be higher than the buyer's budget.

\section{Determination of Profits}

After all offer prices have been received, the auctioneer will determine which parcels were purchased. You will then click on the "Update" button and you will learn whether you sold your parcels. There are three possible profit scenarios:

i) Successful sellers will receive a price equal to their offer, and thus, their profits will be their offer price for that parcel minus the submission cost.

ii) Subjects that submit an offer for a parcel which is too high for the available budget will not receive their offer price, but instead their profits will be their ownership return for that parcel minus the submission cost.

iii) Profits for subjects who do not submit an offer for a parcel will be their ownership return for that parcel.

In Round 1 of the example to the right, the subject earned a total profit of $\$ 156,000$ by successfully selling Parcel 1 for a profit of $\$ 48,000$, earning $\$ 50,000$ profit from Parcel 2 where no offer was submitted, and earning $\$ 58,000$ profit for Parcel 3 that was not successfully sold. Likewise, in round 2 of this example, the subject would earn a total profit of $\$ 89,000$ from selling Parcel 1 and receiving the ownership returns from Parcel 2 and Parcel 3 minus the submission costs for each. 
Your computer will calculate your profits for each parcel in each round, and will keep track of your cumulative earnings. An exchange rate of $3,000,000$ to 1 will be used to converts your earnings from experimental dollars to US dollars. For example, if you earn 60,000,000 experimental dollars will have earned \$20 US to take home today.

\section{Market Information}

In addition to the information regarding your ownership returns and whether you sold your parcels, you will receive information regarding the market (as seen in the example):

Before each round, the administrator will announce:

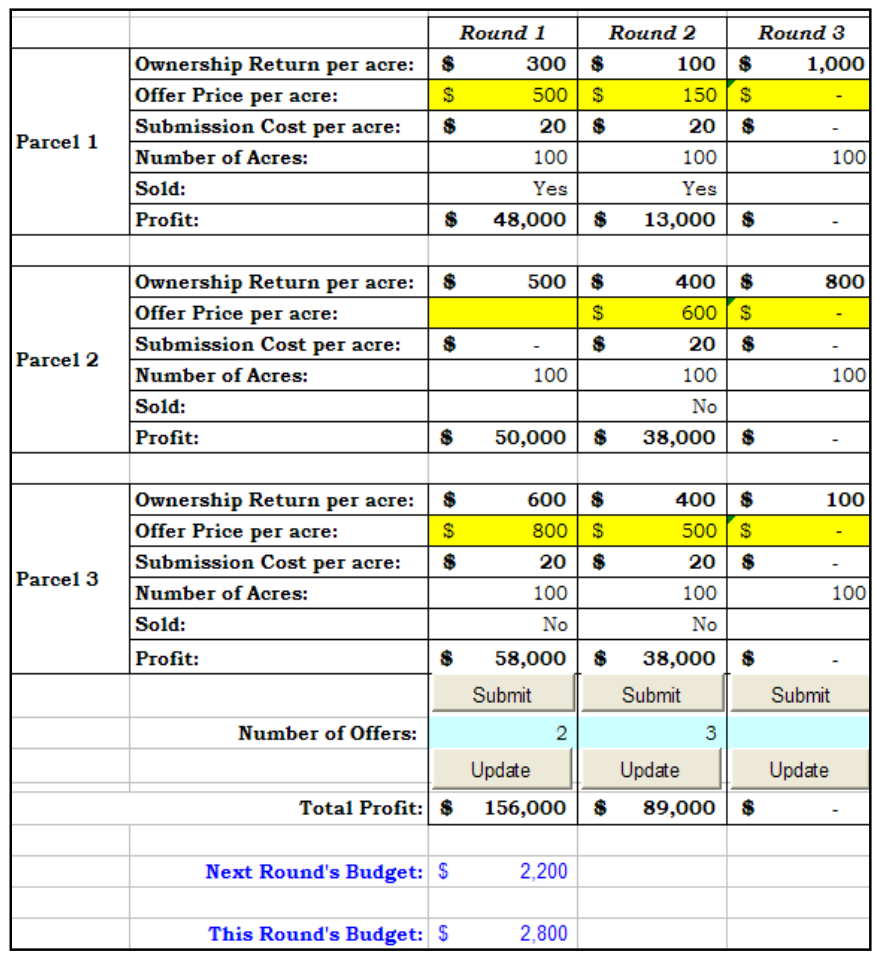

- The buyer's budget for that round.

This information will be recorded on your spreadsheet when you click on the "Update" button after each round. 


\section{Experiment Instructions - Variable Budget with Market Behavior Public Information}

Welcome to this experiment in the economics of decision making. In the course of the experiment, you will have opportunities to earn money. Any money earned is yours to keep. Therefore, please read these instructions carefully. Please do not communicate with other participants during the experiment.

In this experiment, you will participate in a series of market trading rounds. You and all of the other participants in the room will assume the role of landowners and you will be given the opportunity to sell up to three parcels of land. The administrator will be the buyer. In each round, you will need to decide whether you want to keep each of your parcels or try to sell some or all of them - and at what price you want to sell each parcel.

To the right is a hypothetical example, where two rounds have been completed and the third round is just about to begin. On your computer screen, you will note a variety of important information. Each parcel is assigned an

Ownership Return per acre, which is the amount of money that will be added to your profit if that parcel is not sold in that round. The size of each of your three parcels is 100 acres each. In this hypothetical example, the ownership returns in the first round are $\$ 300$ per acre, $\$ 500$ per acre, and $\$ 600$ per acre, respectively. In general, your

\begin{tabular}{|c|c|c|c|c|c|c|c|}
\hline \multirow{7}{*}{ Parcel 1} & \multirow[b]{2}{*}{ Ownership Return per acre: } & \multicolumn{2}{|c|}{ Round 1} & \multicolumn{2}{|c|}{ Round 2} & \multicolumn{2}{|c|}{ Round 3} \\
\hline & & $\$$ & 300 & $\$$ & 100 & $\$$ & 1,000 \\
\hline & Offer Price per acre: & $\$$ & 500 & $\$$ & 150 & $\$$ & - \\
\hline & Submission Cost per acre: & $\$$ & 20 & $\$$ & 20 & $\$$ & - \\
\hline & Number of Acres: & & 100 & & 100 & & 100 \\
\hline & Sold: & & Yes & & Yes & & \\
\hline & Profit: & $\$$ & 48,000 & $\$$ & 13,000 & $\$$ & - \\
\hline \multirow{6}{*}{ Parcel 2} & Ownership Return per acre: & $\$$ & 500 & $\$$ & 400 & $\$$ & 800 \\
\hline & Offer Price per acre: & & & $\$$ & 600 & $\$$ & - \\
\hline & Submission Cost per acre: & $\$$ & - & $\$$ & 20 & $\$$ & - \\
\hline & Number of Acres: & & 100 & & 100 & & 100 \\
\hline & Sold: & & & & No & & \\
\hline & Profit: & $\$$ & 50,000 & $\$$ & 38,000 & $\$$ & - \\
\hline \multirow{10}{*}{ Parce1 3} & Ownership Return per acre: & $\$$ & 600 & $\$$ & 400 & $\$$ & 100 \\
\hline & Offer Price per acre: & $\$$ & 800 & $\$$ & 500 & $\$$ & - \\
\hline & Submission Cost per acre: & $\$$ & 20 & $\$$ & 20 & $\$$ & - \\
\hline & Number of Acres: & & 100 & & 100 & & 100 \\
\hline & Sold: & & No & & No & & \\
\hline & Profit: & $\$$ & 58,000 & $\$$ & 38,000 & $\$$ & - \\
\hline & & \multicolumn{2}{|c|}{ Submit } & \multicolumn{2}{|c|}{ Submit } & \multicolumn{2}{|c|}{ Submit } \\
\hline & \multirow[t]{2}{*}{ Number of Offers: } & \multicolumn{2}{|r|}{2} & \multicolumn{2}{|r|}{3} & \multirow{2}{*}{\multicolumn{2}{|c|}{ Update }} \\
\hline & & \multicolumn{2}{|c|}{ Update } & \multicolumn{2}{|c|}{ Update } & & \\
\hline & Total Profit: & $\$$ & 156,000 & $\$$ & 89,000 & $\$$ & - \\
\hline
\end{tabular}

ownership returns may not be the same as those of other sellers and will change throughout the experiment. Keep in mind that the numbers used in these tables are for instructional purposes only and may not look at all like the numbers you will see during the experiment.

The buyer's budget will be announced before the start of each round. The budget will vary in each round and be between $\$ 3.7$ million and $\$ 13.7$ million with an average of $\$ 8.7$ million. The budget will be determined by having a volunteer subject draw one labeled bingo ball from a bag containing 11 bingo balls labeled 3.7, $4.7 \ldots 12.7,13.7$. The number on the ball represents millions of dollars. For instance, if the ball labeled 8.7 is drawn, then the next round's budget will be $\$ 8.7$ million. The drawn bingo ball will be replaced after each round.

In each round, you must decide whether you want to sell any or all of your parcels and, if so, at what price you are willing to sell each of your parcels. To do this, first, you will indicate the number of offers that you will be typing $0,1,2$, or 3 in the blue box. You will pay a 
submission cost of $\$ 20$ per acre for each parcel for which you submit an offer. Next, you will submit your offer prices confidentially by entering them into the yellow boxes in your spreadsheet. Then, hit "Enter" on your keyboard, and click on the "Submit" button after you have entered offer prices for all of the parcels you are trying to sell. In this example for Round 1, two offers are being made: the offer prices are $\$ 500$ for parcel 1 and $\$ 800$ for parcel 3 .

After everyone has submitted their decisions, the administrator will rank all the offer prices received from lowest to highest and then determine which participants sold their parcels based on the budget for that round. The administrator will purchase as many parcels as possible starting from the lowest offer price and moving up until the available budget is exhausted. For example, imagine that current round budget is $\$ 300$ and eight offer prices were submitted - ranked from lowest to highest:

\section{Offer Prices:}

$\$ 30$

$\$ 40$

$\$ 50 \quad \$ 60$

$\$ 70$

$\$ 80$

$\$ 90 \$ 100$

Parcels are purchased in order (from left to right) until the buyer does not have enough money to purchase another parcel. In the example, the five lowest offer prices $(\$ 30+\$ 40+$ $\$ 50+\$ 60+\$ 70)$ are purchased for a total of $\$ 250$. None of the last three offers are purchased, since even the lowest non-accepted offer of $\$ 80$ would bring the total cost to $\$ 330(\$ 250+\$ 80)$ and therefore be higher than the buyer's budget.

\section{Determination of Profits}

After all offer prices have been received, the auctioneer will determine which parcels were purchased. You will then click on the "Update" button and you will learn whether you sold your parcels. There are three possible profit scenarios:

i) Successful sellers will receive a price equal to their offer, and thus, their profits will be their offer price for that parcel minus the submission cost.

ii) Subjects that submit an offer for a parcel which is too high for the available budget will not receive their offer price, but instead their profits will be their ownership return for that parcel minus the submission cost.

iii) Profits for subjects who do not submit an offer for a parcel will be their ownership return for that parcel.

In Round 1 of the example to the right, the subject earned a total profit of $\$ 156,000$ by successfully selling Parcel 1 for a profit of $\$ 48,000$, earning $\$ 50,000$ profit from Parcel 2 where no offer was submitted, and earning $\$ 58,000$ profit for Parcel 3 that was not successfully sold. Likewise, in round 2 of this example, the subject would earn a total profit 
of $\$ 89,000$ from selling Parcel 1 and receiving the ownership returns from Parcel 2 and Parcel 3 minus the submission costs for each.

Your computer will calculate your profits for each parcel in each round, and will keep track of your cumulative earnings. An exchange rate of 3,000,000 to 1 will be used to converts your earnings from experimental dollars to US dollars. For example, if you earn $60,000,000$ experimental dollars will have earned $\$ 20$ US to take home today.

\section{Market Information}

In addition to the information regarding your ownership returns and whether you sold your parcels, you will receive information regarding the market (as seen in the example):

Before each round, the administrator will announce:

- The buyer's budget for that round.

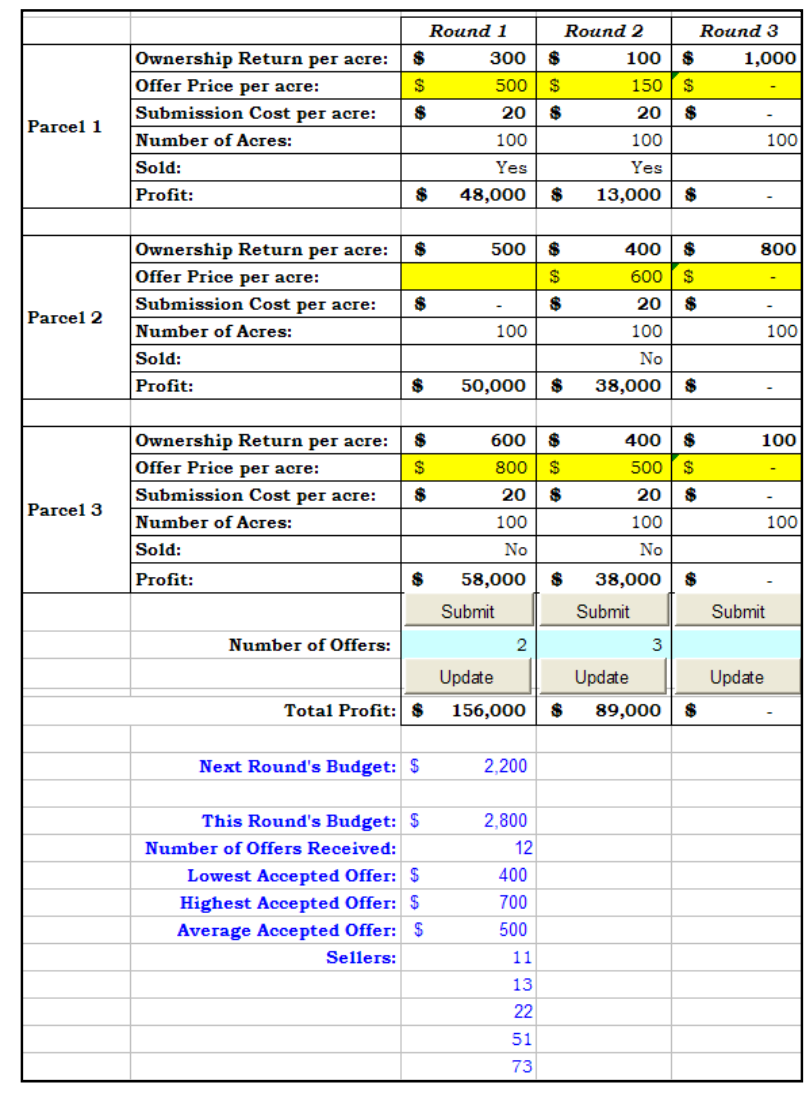

After each round, the administrator will announce:

- The number of offers submitted to the market,

- The price of the lowest accepted offer,

- The price of the highest accepted offer,

- The average price of the accepted offers, and

- The subjects that successfully sold their parcels.

All of this information will be recorded on your spreadsheet when you click on the "Update" button after each round. 


\section{The Department of Applied Economics and Statistics College of Agriculture and Natural Resources University of Delaware}

The Department of Applied Economics and Statistics carries on an extensive and coordinated program of teaching, organized research, and public service in a wide variety of the following professional subject matter areas:

\section{Subject Matter Areas}

Agricultural Policy

Food and Agribusiness Management and Marketing

Natural Resource Management

Rural and Community Development
Environmental and Resource Economics

International Agricultural Trade

Price and Demand Analysis

Statistical Analysis and Research Methods

The department's research in these areas is part of the organized research program of the Delaware Agricultural Experiment Station, College of Agriculture and Natural Resources. Much of the research is in cooperation with industry partners, the USDA, and other State and Federal agencies. The combination of teaching, research, and service provides an efficient, effective, and productive use of resources invested in higher education and service to the public. Emphasis in research is on solving practical problems important to various segments of the economy.

The mission and goals of our department are to provide quality education to undergraduate and graduate students, foster free exchange of ideas, and engage in scholarly and outreach activities that generate new knowledge capital that could help inform policy and business decisions in the public and private sectors of the society. APEC has a strong record and tradition of productive programs and personnel who are engaged in innovative teaching, cutting-edge social science research, and public service in a wide variety of professional areas. The areas of expertise include: agricultural policy; environmental and resource economics; food and agribusiness marketing and management; international agricultural trade; natural resource management; operations research and decision analysis; rural and community development; and statistical analysis and research methods. 
APEC Research

Reports are published

by the Department of

Applied Economics

and Statistics, College

of Agriculture and

Natural Resources of

the University of

Delaware.

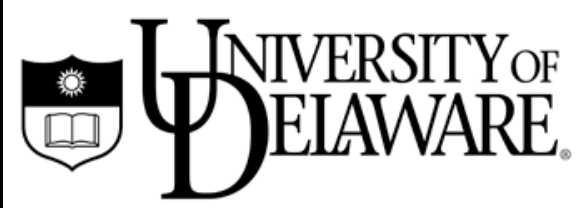

